\title{
Chemical composition and antioxidant studies of underutilized part of mangosteen (Garcinia mangostana L.) fruit
}

\author{
Abdul Rohman ${ }^{1 *}$, Mohamad Rafi², Gemini Alam³, Muchtaridi Muchtaridi', Anjar Windarsih ${ }^{5}$ \\ ${ }^{1}$ Department of Pharmaceutical Chemistry, Faculty of Pharmacy, Gadjah Mada University, Yogyakarta, Indonesia. \\ ${ }^{2}$ Department of Chemistry, Faculty of Mathematics and Natural Sciences, Bogor Agricultural University, Kampus IPB Dramaga, Bogor, Indonesia. \\ ${ }^{3}$ Faculty of Pharmacy, Hasanuddin University, Makassar, Indonesia. \\ ${ }^{4}$ Department of Pharmaceutical Analysis and Medicinal Chemistry, Faculty of Pharmacy, Universitas Padjadjaran, Sumedang, Indonesia. \\ ${ }^{5}$ Research Unit for Natural Product Technology (BPTBA), Indonesian Institute of Sciences (LIPI), Yogyakarta, Indonesia.
}

\section{ARTICLE INFO \\ Received on: 05/04/2019 \\ Accepted on: 20/05/2019 \\ Available online: 03/08/2019}

Key words:

Mangosteen's peel, antiradical, underutilized part, in vitro antioxidants, xanthones, DPPH.

\begin{abstract}
Mangosteen (Garcinia mangostana L) is one of Indonesian fruit with export commodity due to its sweet-sour and pleasant taste. The pulp of this fruit is frequently consumed freshly, while the seed and peel are removed and become a waste. The chemical components contained in mangosteen's seed and peel, especially xanthones, have been reported as antioxidants either in vitro or in vivo. Several traditional medicine products used the extracts of mangosteen as one of its components; therefore, the characterization of mangosteen extracts through identification of its active components is very important. This review article highlighted the updates on the characterization and antioxidant activities of mangosteen's seed and peel to prove that the wastes of mangosteen fruit could be advantageous to be developed as functional food as antioxidants. Several databases have been used during performing this review, including PubMed, Scopus, Biological abstracts, chemical abstracts, and Google Scholar.
\end{abstract}

\section{INTRODUCTION}

There are some evidences and are supported by scientific publications that phytochemicals contained in fruits are believed to play a beneficial role in the prevention and the treatment of degenerative diseases. Currently, with the jargon "back to nature," there is a great interest in the potential health benefits of exotic fruits due to their antioxidant content and bioactive compounds. Among the exotic fruit commonly consumed is mangosteen or known with "Buah Manggis" in Indonesia (Aramwit et al., 2010; Hait-Darshan et al., 2009). Mangosteen with scientific name of Garcinia mangostana L. is a tropical queen of fruits, belonging to the family of Clusiaceae commonly found in throughout India and Southeast Asia, such as Indonesia, Malaysia, Myanmar, Philippines, Sri Lanka, and Thailand (Ji et al., 2017). For Indonesia,

"Corresponding Author

Abdul Rohman, Department of Pharmaceutical Chemistry, Faculty of

Pharmacy, Universitas Gadjah Mada, Yogyakarta, Indonesia.

E-mail:abdulkimfar@gmail.com magosteen has emerged as one of the export commodities of fruits because of its sweet-sour and pleasant taste (Muchtaridi et al., 2017). Mangosteen is cultivated, especially as a source of its highly palatable fruit, which consisted of pulp, contained in a dark purple rind. This fruit is commonly consumed freshly, as a consequence, the peel and seed of mangosteen fruit resulted high amount of wastes. Therefore, some scientists try to take the advantage of the underutilized part (peel and seed) of mangosteen fruit as one of herbal components (Ovalle-Magallanes et al., 2017).

Nowadays, the use of underutilized part of mangosteen, especially peel and seed have increased exponentially, as seen by the huge number of herbal products available in herbal markets containing mangosteen peel, such as Mastin ${ }^{(\mathrm{R})}$ and SidoMuncul SARI KULIT MANGGIS $^{(\mathrm{R})}$ (Indonesia), Mangosteen Xango (Malaysia), as well as Mangosteen pericarp Acne Cream $^{(\mathrm{R})}$ and Mangosteen powder $^{(\mathrm{R})}$ (Thailand) (Limphapayom et al., 2017). Some modern pharmaceutical formulas containing mangosteen peel extract have been developed by some pharmaceutical formulators, including the encapsulation of nanoemulsions of mangosteen peel extract intended as topical formulation (Mulia et al., 2018a). The encapsulation of 
mangosteen extract in nanoemulsions is promising strategy to utilize the active compound contained, particularly $\alpha$-mangostin. Mulia et al. (2018b) developed nanoemulgel mangosteen extract in virgin coconut oil for topical formulation. The developed nanoemulgels exhibited better penetration ability than its nanoemulsion. Pratiwi et al. (2017) developed self-nanoemulsifying drug delivery system (SNEDDS) with enhanched solubilization of ethanol extract from mangosteen peel intended for treatment of topical gangrene foot. Previously, SNEDDS from ethyl acetate extract of mangosteen peel intended for the improvement of diffusion and precut absorption was previously developed (Pratiwi et al., 2016).

Traditionally, underutilized form of mangosteen (peel and seed) in the form of infusions and decoctions has been used to treat infections of skin, urinary tract, and gastrointestinal, and has been believed to act as laxative, anti-scorbutic, and anti-fever agent (Ovalle-Magallanes et al., 2017). Besides, peel and seed of mangosteen have been reported for the treatment of diarrhea, abdominal pain, dysentery, suppuration, wound infection, and chronic ulcer (Cui et al., 2010; Gorinstein et al., 2011; Suksamram et al., 2006) and to treat inflammatory and immunological relateddiseases, such as acne, food allergies, and arthritis (Wang et al., 2017). These activities indeed need to be correlated with the chemical composition contained in mangosteen's seed and peel (Genovese et al., 2016).

\section{METHODS}

During performing this review, we used several databases, including Scopus, PubMed, and Google Scholar to identify and to download the abstracts, reports, and research papers related to chemical composition, characterization, and antioxidant activities of mangosteen's peel and mangosteen's seed. The keywords used during searching of information was (antioxidant + mangosteen peel or mangosteen seed + chemical composition + in vitro + in vivo) in the month of February-March 2019.

\section{CHEMICAL CONSTITUENTS OF MANGOSTEEN'S PEEL}

The peel of mangosteen fruit has been reported to contain some phenolic compounds, such as tannins, flavonoids, xanthones, and other bioactive substances which support the medicinal properties (Pothitirat et al., 2009). Some chemical compounds or secondary metabolites have been isolated from Mangosteen rind which includes xanthones (a class of polyphenolic compounds with a characteristic tricyclic aromatic ring system) or xanthen$9 \mathrm{H}$-ones. Of the 40 xanthones present in the pericarp of the fruit, the most abundant xanthones found are $\alpha$-mangostin, $\beta$-mangostin, and $\gamma$-mangostin (Chen et al., 2008; Pedraza-Chaverrí et al., 2009; Zarena and Sankar, 2011). Mangostins $(\alpha-, \beta$ - and $\gamma-)$ are the most frequently studied. They have a unique chemical structure with a tricyclic aromatic system carrying isoprene, methoxyl and hydroxyl groups (Fig. 1). Some biological activities either in vitro or in vivo are correlated with the contents of these mangostins, including antibacterial, antifungal, antimalarial, anticarcinogenic, and antiatherogenic activities (Obolskiy et al., 2009).

The other and new xanthones are found, namely, isogarcinol (Chen et al., 2017), garcinone E, 9-hydroxycalabaxanthone, 8-deoxygartanin, and gartanin 1,3,6,7-tetrahydroxy-2,8-(3-methyl-2-butenyl), [1,3,6-trihydroxy- 7-methoxy-2,8-(3-methyl-2-butenyl)xanthone], 1,3,7-Trihydroxy2,8-di- (3-methylbut-2-enyl)xanthon, 1,7-dihydroxy-3methoxy2-(3-methylbut-2-enyl)xanthon (Wittenauer et al., 2012), mangostanaxanthones V and VI, mangostanaxanthone $\mathrm{IV}$, garcimangosone $\mathrm{D}$, aromadendrin-8-C- $\beta$-D-glucopyranoside, 1,2,4,5-tetrahydroxybenzene, 2,4,3'-trihydroxybenzophenone-6$\mathrm{O}-\beta$-glucopyranoside, maclurin-6-O- $\beta$-D-glucopyranoside, and 2,4,6,3',5'-pentahydroxybenzophenone (Mohamed et al., 2017), and epicatechin (Yu et al., 2007). In addition, Jung et al. (2006) have isolated two highly oxygenated prenylated xanthones, namely, 8-hydroxycudraxanthone $\mathrm{G}$ and mangostingone or [7-methoxy2-(3-methyl-2-butenyl)-8-(3-methyl-2-oxo-3butenyl)-1,3,6-trihydroxyxanthone, along with cudraxanthone $\mathrm{G}$, 8-deoxygartanin, and garcimangosone $\mathrm{B}$.

The composition of chemical constituents depending on several factors such as maturity, locations of cultivation, and extracting solvents. Pothitirat et al. (2009) evaluated the chemical compositions of active compounds ( $\alpha$-mangostin, total phenolics, flavonoids, and tannin contents) in mangosteen peel at two stages of maturity (young and mature). The young and mature of ethanolic $(95 \%)$ extracts of mangosteen rind contained $\alpha$-mangostin of 8.07 \pm 0.11 and $13.63 \pm 0.06 \% \mathrm{wt} / \mathrm{wt}$ of extract, respectively. The mature of mangosteen also have the higher contents of phenolics, flavonoids, and tannin significantly than the young ones.

Muchtaridi et al. (2017) have evaluated the levels of $\alpha$-mangostin, $\gamma$-mangostin, and gartanin in ethanolic $(70 \%)$ extracts of Mangosteen rind from four different locations in Indonesia (Bogor, Purwakarta, Subang, and Tasikmalaya). The analysis showed that the levels of $\alpha$-mangostin, $\gamma$-mangostin, and gartanin are $13.87 \%, 8.28 \%$ and $10.44 \%$, respectively, from Bogor; $10.07 \%, 6.33 \%$, and $8.76 \%$ from Purwakarta; $10.88 \%$, $6.01 \%, 8.08 \%$ from Subang and $8.53 \%, 6.07 \%, 17.28 \%$ from Tasikmalaya, respectively.

Kusmayadi et al. (2018) have evaluated the effects of extracting solvents, namely, methanol, ethanol, acetone, hexane, ethyl acetate, acetic acid, and aquadest used during extraction of mangosteen peel at different times (24, 36, and 48 hours). The results showed that acetone was the best solvent used for xanthon extraction with time extraction of 36 hours which is not significantly different at 48 hours $(p<0.05)$. Ghasemzadeh et al. (2018) also investigated the effects of solvents for extraction of $\alpha$-mangostin mangosteen peel extract along with extraction time, microwave power, and solvent percentage using experimental design approach of response surface methodology. The ethyl acetate was the best solvents capable of extracting the highest concentration of $\alpha$-mangostin, followed by dichloromethane, ethanol, and water. The extraction condition also affected the antioxidant activities in vitro of mangosteen peel. Samuagam et al. (2013) have optimized the extraction condition (ethanol percentage, time extraction, and temperature) and the optimum conditions to get maximum yield of extract were $60 \%$ ethanol concentration for 60 minutes at $25^{\circ} \mathrm{C}$. Using this condition, the mangosteen peel extract revealed $\mathrm{IC}_{50}$ value of $19.75 \mu \mathrm{g} / \mathrm{mL}$ (DPPH radical scavenging assay), $54.66 \%$ nitric oxide scavenging activity, and 79.94\% $\beta$-carotene bleaching (BCB) assay.

\section{ANTIOXIDENT ACTIVITIES}

Several methods have been used for the evaluation of antioxidant activities in vitro, including radical scavenging 

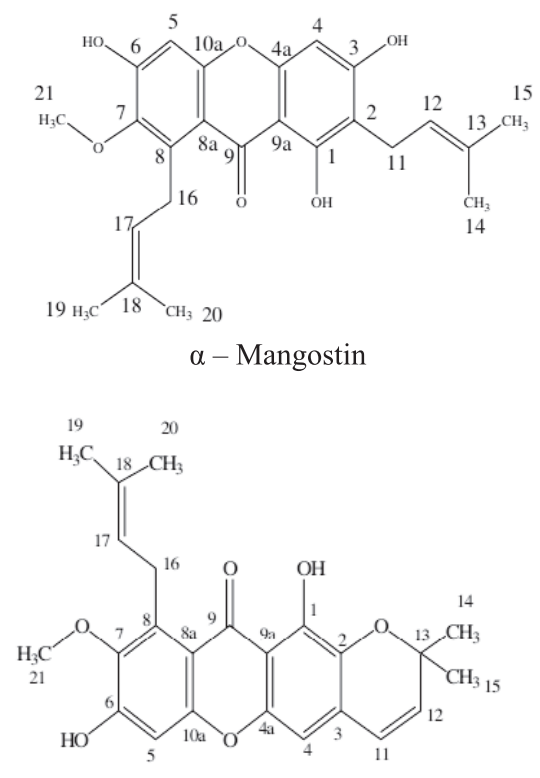

9- Hydroxycalabaxanthone

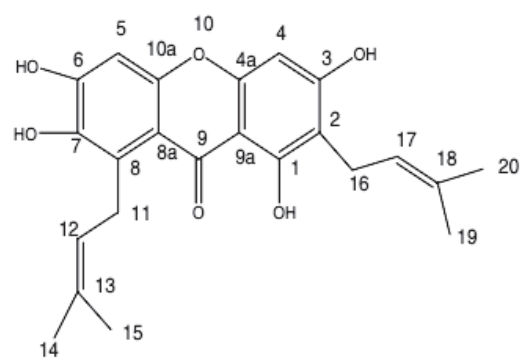

1,3,6,7-quadhydroxy-3-methoxy-2,8-(3methyl-2-butenyl) xanthone

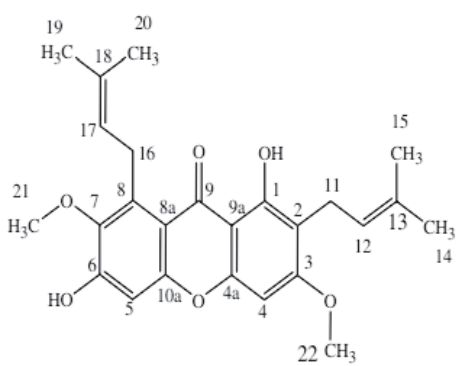

$\beta$ - Mangostin

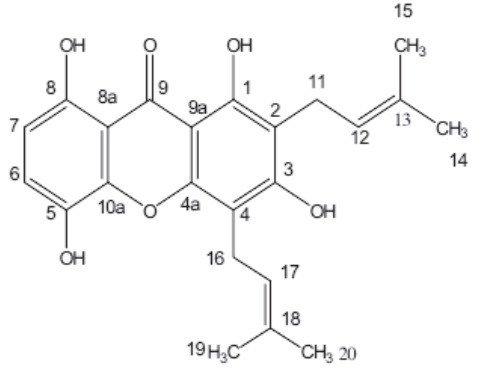

Gartanin

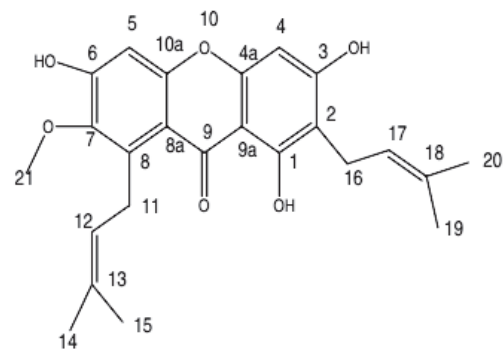

1,3,6-trihydroxy-3-methoxy-2,8-(3-methyl-

2- butenyl)xanthone<smiles>CC(C)=CCc1c(O)cc2oc3cc(O)c(O)c(CC=C(C)C)c3c(=O)c2c1O</smiles><smiles>CC(C)=CCc1c(O)c(CC=C(C)C)c2oc3c(O)cccc3c(=O)c2c1O</smiles>

8-Deoxygartanine

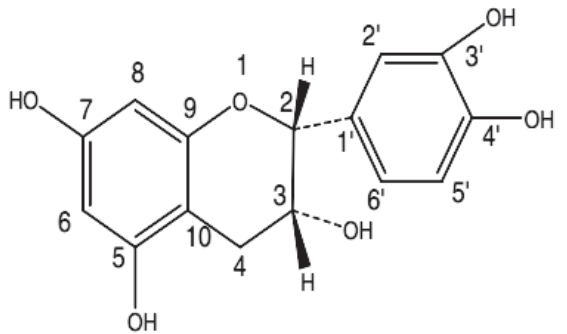

epicatechin

Figure 1. Some chemical compounds isolated from rind and seed of mangosteen fruit.

activities using radicals of 1,1-diphenyl-2-picrylhydrazyl (DPPH) and 2,2-azinobis(3-ethylbenzothia-zoline-6-sulfonic acid) diammonium salt (ABTS) cation, superoxide anion $\left(\mathrm{O}_{2}{ }^{-}\right)$, nitric oxide ( $\mathrm{NO})$, peroxynitrite $\left(\mathrm{ONOO}^{-}\right)$, and hydroxyl radical $(\cdot \mathrm{OH})$, the deoxyribose assay, oxygen radical absorbance capacity (ORAC), chelating activity using ferrous ion $\left(\mathrm{Fe}^{2+}\right)$, ferric reducing antioxidant power (FRAP), phosphomolybdenum method, cytochrome $c$ reducing capacity, ferric thiocyanate method, and thiobarbituric acid assay (Suttirak and Manurakchinakorn, 2012).

\section{Radical scavenging activities using DPPH radical}

Among radicals used for modeling, the antioxidant activities of samples in vitro, DPPH and ABTS radicals are the most reported in scientific literature. The scavenging activity of DPPH radical measures the capability of evaluated samples to donate hydrogen radicals to capture DPPH radical (DPPH'). The color changes of DPPH solution from a deep purple to a light yellow as indicated by decreased absorbance at 515-517 nm (Surveswaran et al., 2007). Phenolics and flavonoids are typical compounds capable of donating radical hydrogens (Yu et al., 2007). Tjahjani et al. (2014) have evaluated DPPH radical scavenging activities of ethanolic extracts $(96 \%$ and $70 \%)$ and fractions of hexane, ethyl acetate, butanol, and water of mangosteen peel. The antioxidant activities were expressed with inhibition concentration of $50 \%$ of radical $\left(\mathrm{IC}_{50}\right)$. The lower IC50 indicated the more active of evaluated samples. Hexane fraction showed the most active antiradical with $\mathrm{IC}_{50}$ of $3.62 \pm 0.04 \mu \mathrm{g} / \mathrm{ml}$, followed by $70 \%$ ethanol extract, $96 \%$ ethanol extract, and ethyl acetate extract with $\mathrm{IC}_{50}$ values of $6.56 \pm$ $0.31,7.48 \pm 0.19$, and $13.29 \pm 0.12 \mu \mathrm{g} / \mathrm{ml}$, respectively.

Palakawong et al. (2010) have evaluated the 50\% ethanolic extracts of peel, leaves, and bark of mangosteen. Among these samples, the peel extract showed the highest antiradical activities using DPPH radicals with $\mathrm{IC}_{50}$ of $5.94 \mu \mathrm{g} / \mathrm{ml}$, followed by bark 6.46 and leaves $9.44 \mu \mathrm{g} / \mathrm{ml}$. However, the antioxidant of evaluated extracts was lower than that of vitamin $\mathrm{C}$ used as a positive control with $\mathrm{IC}_{50}$ of $4.30 \mu \mathrm{g} / \mathrm{ml}$. This study obtained $\mathrm{IC}_{50}$ values less than those reported by Weecharangsan et al. (2006) using the same extraction methods, in which $50 \%$ of ethanolic extract of mangosteen peel was of $30.7 \mu \mathrm{g} / \mathrm{ml}$. The difference in $\mathrm{IC}_{50}$ values could be explained that the used mangosteen samples were in the different maturity stage, in which Palakawong et al. (2010) used mangosteen in maturity stage of 3 , while Weecharangsan et al. (2006) used the maturity stage of 5 or 6 . Supiyanti et al. (2010) also reported that $\mathrm{IC}_{50}$ of ethanolic extract of mangosteen peel was about $8.56 \mu \mathrm{g} / \mathrm{ml}$, while vitamin $\mathrm{C}$ as positive control had $\mathrm{IC}_{50}$ of $3.37 \mu \mathrm{g} / \mathrm{ml}$. 
The antiradical scavenging activity of mangosteen peel extracts expressed by \%inhibition has been used for comparative studies of extracting solvents (methanol, ethanol, acetone, and aqueous). At the same concentration, aqueous extract exhibited the highest radical scavenging activity compared methanol, ethanol, and acetone with \%inhibition of $67.45 \pm 1.05 \%, 18.81 \pm 1.44 \%$, $46.97 \pm 0.29 \%$, and $9.19 \pm 1.77 \%$, respectively (Kamaludin et al., 2016). DPPH radical assay was also used to compared $80 \%$ ethanol extract of peel and pulp of yellow mangosteen (Garcinia tinctoria), and the results showed that mangosteen peel had higher antiradical assay $\left(\mathrm{IC}_{50}\right.$ of $\left.48.8 \mu \mathrm{g} / \mathrm{ml}\right)$ than that of pulp $\left(\mathrm{IC}_{50}\right.$ of $\left.153.2 \mu \mathrm{g} / \mathrm{ml}\right)$. This result corresponds to the levels of total phenolic contents present in peel and pulp of mangosteen fruit (Arazo et al., 2011).

Mangosteen peel extracts (ethanol 7\%) has been formulated as oral solution dosage forms and its antioxidant properties have been assessed using DPPH radical scavenging activity. Xanthones, the active compounds contained in mangosteen peel, are not soluble in water, therefore some co-solvents, namely, polyethylene glycol (PEG) 400-glycerol (20-20, 20-40, 40-20, 40-40) are optimized intended to improve its solubility. Oral solution with the composition of co-solvents of PEG 400-glycerol (40:40) has the highest DPPH radical scavenging activity with $\mathrm{IC}_{50}$ of $24.81 \mu \mathrm{g} / \mathrm{ml}$ (Sumarny et al., 2014). The $\mathrm{IC}_{50}$ obtained was indeed lower than that of its extract due to the addition of co-solvents in the formula with no activity as radical scavenger.

\section{ABTS radical scavenging activities}

ABTS (2,2'-azinobis(3-ethylbenzothiazoline-6-sulfonic acid)) radical scavenging method was used to confirm the results obtained from DPPH radical scavenging since both methods are based on a similar antioxidant mechanism and both radicals used were soluble in polar solvents (methanol and ethanol). This assay measures the ability of antioxidants to scavenge stable radical cation ABTS + having blue-green color with maximum absorption at $734 \mathrm{~nm}$ which decreases in its intensity due to the presence of antioxidants (Zhong and Shahidi, 2015). The ABTS scavenging activity of mangosteen's peel and seed on free radical ABTS was compared with amount of trolox (standard), as a consequence, ABTS radical scavenging activity was expressed as trolox equivalent antioxidant capacity (TEAC). Okonogi et al. (2007) evaluated ABTS radical scavenging of 95\% ethanol extract of mangosteen peel, and the results showed that extract had TEAC of $3.00 \pm 0.016(\mathrm{mM} / \mathrm{mg})$, higher than the same extract of Banana, Coconut, Dragon fruit, Passion fruit, and Long-gong with TEAC values of $1.80 \pm 0.038,1.53 \pm 0.044,0.685 \pm 0.001,0.591 \pm$ 0.008 , and $0.207 \pm 0.002 \mathrm{mM} / \mathrm{mg}$ extract, respectively. The same results (TEAC value of $3.00 \pm 0.016 \mathrm{mM} / \mathrm{mg}$ ) were also obtained by Tachakittirungrod et al. (2007). In addition, Surveswaran et al. (2007) reported that TEAC value of ethanol extract of mangosteen peel was $3.91 \mathrm{mM} / \mathrm{mg}$, comparable to that reported by Okonogi et al. (2007). The TEAC values of ethyl acetate and acetone extracts of mangosteen peel were also reported, i.e., 3.821 and $3.815 \mu \mathrm{M} /$ $\mathrm{ml}$ (Zarena and Sankar, 2009). Xanthoses (mangostins, garcinone-E, methoxy-bmangostin, garcimangosone $\mathrm{A}$, garcimangosone $\mathrm{B}$, garcimangosone $\mathrm{C}$ ) present in mangosteen were reported to be responsible for this antioxidant activity.

\section{Peroxynitrite scavenging activity}

Peroxynitrite (ONOO-) scavenging activity is analyzed by monitoring the oxidation of dihydrorhodamine 123
(DHR 123). In this procedure, DHR 123 is oxidized by native $\mathrm{ONOO}^{-}$and $\mathrm{ONOO}^{-}$-derived from the peroxynitrite donor 3-morpholinosydnonimine hydrochloride (SIN-1). The oxidized DHR 123 is then evaluated by the luminescence spectrophotometer using excitation wavelength of $480 \mathrm{~nm}$ and emission wavelength of $530 \mathrm{~nm}$. The peroxynitrite scavenging activity could be related to the fluorescence intensities of oxidized DHR 123 (Zou et al., 2005). The radical activity was expressed as $\mathrm{IC}_{50}$ values. Jung et al. (2006) have evaluated 14 compounds isolated from mangosteen peel. Among these compounds, smeathxanthone A, $\gamma$-mangostin, and gartanin showed the highest peroxynitrite radical scavenging activities with $\mathrm{IC}_{50}$ values of $2.2,8.0$, and $9.1 \mu \mathrm{M}$, respectively. As positive control, DL-penicillamine had $\mathrm{IC}_{50}$ value of $3.1 \mu \mathrm{M}$.

\section{Ferric reducing power}

Ferric reducing antioxidant power (FRAP) measures the reducing power of samples. FRAP assay is relied on the ability of the antioxidant to reduce $\mathrm{Fe}^{3+}$ to $\mathrm{Fe}^{2+}$ in the presence of TPTZ (2,4,6-tripyridyl-s-triazine) resulted an intense blue color of $\mathrm{Fe}^{2+}$ TPTZ complex with an absorption maximum at $593 \mathrm{~nm}$ (Yang and Zhai, 2010). Azima et al. (2014) have evaluated the reducing power of mangosteen peel extracts. The sample preparation was carried out by stirring samples in $100 \mathrm{mM}$ citrate buffer $(\mathrm{pH}$ 3.0 ) in the ration $1: 4$ for 10 minutes at $100^{\circ} \mathrm{C}$. The filtrate were collected and evaporated by using rotary evaporator at $60^{\circ} \mathrm{C}$ and 114 mbar. The mangosteen peel extract had the highest FRAP with FRAP value of $79.37 \pm 0.77 \mathrm{~A} \mathrm{mM} / \mathrm{g}$ Trolox equivalent antioxidant capacity (TEAC) compared to guava peel extract (FRAP value of $25.66 \pm 1.40 \mathrm{mM} / \mathrm{g}$ TEAC) and Clitoria ternatea extract (13.32 \pm $0.28 \mathrm{mM} / \mathrm{g}$ TEAC). This antioxidant activity correlated with the contents of antocyanin.

In vivo antioxidant activity of $80 \%$ ethanolic extract of mangosteen has been evaluated by Samuagam et al. (2015). In this study, rats were treated with mangosteen peel extracts for 14 and 30 days with dose of $100 \mathrm{mg} / \mathrm{kg} /$ day, orally, and the liver was taken for antioxidant assays. For positive control, vitamin E was used. The results showed that rats given with mangosteen's peel extract exhibited the significant increase $(p<0.05)$ of enzymatic antioxidants (catalase, superoxide dismutase, glutathione reductase, and lipid peroxidation levels) compared with no treatedrats group (control group).

\section{CONCLUSION}

Mangosteen peel can be considered as the wastes due to the consumption of mangosteen fruit. With the potentiality of underutilized part of fruit as antioxidant, some scientists have explored the possibility mangosteen peel as functional food or food component with beneficial effects on human health. Mangosteen peel contained high amount of phenolic compounds, such as mangostin and gartanin, which are believed to be responsible for antioxidant activities. Mangosteen peel has been reported to have antioxidant activities either in vitro or in vivo, having potential to be developed as food antioxidants.

\section{ACKNOWLEDGMENTS}

We would like to thank the Consortium of World Class Research University for financial support through Program Penelitian Kolaborasi Indonesia 2019 with contract number 2053/ UN1.PIII/DIT-LIT/LT/2019. 


\section{COMPETING INTERESTS} interests.

The authors declare that they have no competing

\section{REFERENCES}

Aramwit P, Bang N, Srichana T. The properties and stability of anthocyanins in mulberry fruits. Food Res Int, 2010; 43:1093-7.

Arazo M, Bello A, Rastrelli L, Montelier M, Delgado L, Panfet C. Antioxidant properties of pulp and peel of yellow mangosteen fruits. Emir J Food Agr, 2011; 23:517-24.

Azima SAM, Noriham A, Manshoor N. Anthocyanin content in relation to the antioxidant activity and colour properties of Garcinia mangostana peel, Syzigium cumini and Clitoria ternatea extracts. Int Food Res, J 2014; 21(6):2369-75.

Chen S, Han K, Li H, Cen J, Yang Y, Wu H, Wei Q. Isogarcinol extracted from Garcinia mangostana L. ameliorates imiquimod-induced psoriasis-like skin lesions in mice. J Agric Food Chem, 2017; 65:846-57.

Chen LG, Yang LL, Wang CC. Anti-inflammatory activity of mangostins from Garcinia mangostana. Food Chem Toxicol, 2008; 46: $688-93$.

Cui J, Hu W, Cai Z, Liu Y, Li S, Tao W, Xiang H. New medicinal properties of mangostins: analgesic activity and pharmacological characterization of active ingredients from the fruit hull of Garcinia mangostana L. Pharmacol Biochem Behavior, 2010; 95:166-72.

Ghasemzadeh A, Jaafar HZE, Baghdadi A, Tayebi-Meigooni A. Alpha-mangostin-rich extracts from mangosteen pericarp: optimization of green extraction protocol and evaluation of biological activity. Molecules, 2018; 23:1852-9.

Genovese S, Fiorito S, Taddeo VA, Epifano F. Recent developments in the pharmacology of prenylated xanthones. Drug Discov Today, 2016; 21:1814-9.

Gorinstein S, Poovarodom S, Leontowicz H, Leontowicz M, Namiesnik J, Vearasilp S, Haruenkit R, Ruamsuke P, Katrich E, Tashma Z. Antioxidant properties and bioactive constituents of some rare exotic Thai fruits and comparison with conventional fruits In vitro and in vivo studies. Food Res Int, 2011; 44:2222-32.

Hait-Darshan R, Grossman S, Bergman M, Deutsch M, Zurgil N. Synergistic activity between a spinach-derived natural antioxidant (NAO) and commercial antioxidants in a variety of oxidation systems. Food Res Int, 2009; 42:246-53.

Ji X, Avula B, Khan IA. Quantitative and qualitative determination of six xanthones in Garcinia mangostana L. by LC-PDA and LC-ESI-MS. J Pharm Biomed Anal, 2007; 43:1270-6.

Jung HA, Su BN, Keller WJ, Mehta RG, Kinghorn AD. Antioxidant xanthones from the pericarp of Garcinia mangostana (Mangosteen). J Agric Food Chem, 2006; 54:2077-82.

Kamaludin NHI, Mun LS, Sa'adi RA. Evaluation of antioxidan activity of some tropical fruit peel extracts: extraction conditions optimization of rambutan peel extract. ARPN J Eng Appl Sci, 2016; 11(3):1623-31.

Kusmayadi A, Adriani L, Abun A, Muchtaridi M, Tanuwiria UH. The effect of solvents and extraction time on total xanthone and antioxidant yields of mangosteen peel (Garcinia mangostana L.) extract. Drug Inv Today, 2018; 10:2572-76.

Limphapayom W, Satayawut K, Wattanavichit W, Pisalwadcharin A, Sukhasem S. Development of technologies for xanthone powder production from mangosteen. International Symposium on Durian and Other Humid Tropical Fruits. Acta Hortic, 2017; 1186:185-8.

Mohamed GA, Al-Abd AM, El-halawanye AM, Abdallaha HM, Ibrahim SRM. New xanthones and cytotoxic constituents from Garcinia mangostana fruit hulls against human hepatocellular, breast, and colorectal cancer cell lines. J Ethnopharmacol, 2017; 198:302-12.

Muchtaridi M, Puteri NA, Milanda T, Musfiroh I. Validation analysis methods of A-Mangostin, $\Gamma$-Mangostin, And gartanin mixture in mangosteen (Garcinia mangostana L.) fruit rind extract from West Java with HPLC. J App Pharm Sci, 2017; 7(10):125-30

Mulia K, Putri GA, Krisanti E. Encapsulation of mangosteen extract in virgin coconut oil based nanoemulsions: preparation and characterization for topical formulation. Materials Sci Forum, 2018a; 929:234-42.

Mulia K, Ramadhan RMA, Krisanti EA. Formulation and characterization of nanoemulgel mangosteen extract in virgin coconut oil for topical formulation. MATEC Web Conf, 2018b; 156:01013.

Obolskiy D, Pischel I, Siriwatanametanon N, Heinrich M. Garcinia mangostana L.: a phytochemical and pharmacological review [J]. Phytother Res, 2009; 23:1047-65.

Okonogi S, Duangrat C, Anuchpreeda S, Tachakittirungrod S, Chowwanapoonpohn S. Comparison of antioxidant capacities and cytotoxicities of certain fruit peels. Food Chem, 2007; 103:839-46.

Ovalle-Magallanes B, Eugenio-Perez D, Pedraza-Chaverri J. Review: medicinal properties of mangosteen (Garcinia mangostana L.): a comprehensive update. Food Chem Toxicol, 2017; 109:102-22.

Palakawong C, Sophanodora P, Pisuchpen S, Phongpaichit S. Antioxidant and antimicrobial activities of crude extracts from mangosteen (Garcinia mangostana L.) parts and some essential oils. Int Food Res J, 2010; 17:583-9.

Pedraza-Chaverrí J, Reyes-Fermín LM, Nolasco-Amaya EG, Orozco-Ibarra M, MedinaCampos ON, González-Cuahutencos O, RiveroCruz I, Mata R. ROS scavenging capacity and neuroprotective effect of $\alpha$-mangostin against 3-nitropropionic acid in cerebellar granule neurons. Exp Toxicol Pathol, 2009; 61:491-501.

Pothitirat W, Chomnawang MT, Supabphol R, Gritsanapan W. Comparison of bioactive compounds content, free radical scavenging and anti-acne inducing bacteria activities of extracts from the mangosteen fruit rind at two stages of maturity. Fitoterapia, 2009; 80:442-7.

Pratiwi L, Fudholi A, Martien R, and Pramono S. Design and optimization of self-nanoemulsifying drug delivery systems (SNEDDS) of ethyl acetate fraction from mangosteen peel (Garcinia mangostana, L.). Int J PharmTech Res, 2016; 9:380-7.

Pratiwi L, Sari R, Apridamayanti P. Self-nanoemulsifying drug delivery system (SNEDDS) with enhanched solubilization of ethanol extract from mangosteen peels (garcinia mangostana, 1.) for treatment of topical gangrene foot: Design and optimization. Int J Drug Deliv Technol, 2017; 7:314-9.

Samuagam L, Sia CM, Akowuah GA, Okechukwu PN, Yim HS The effect of extraction conditions on total phenolic content and free radical scavenging capacity of selected tropical fruits' peel. Health Environ J, 2013; $4(2): 80-102$.

Samuagam L, Sia CM, Akowuah GA, Okechukwu PN, Yim HS. In vivo antioxidant potentials of Rambutan, Mangosteen, and Langsat peel extracts and effects on liver enzymes in experimental rats. Food Sci Biotechnol, 2015; 24(1):191-8.

Suksamram S, Komutiban O, Ratananukul P, Chimnoi N, Lartpornmatulee N, Suksamram A. Cytotoxic prenylated xanthones from the young fruit of Garcinia mangostana. Chem Pharm Bull, 2006; 54: $301-5$.

Sumarny R, Sofiah S, Nurhidayati L, Fatimah. 2014. Antioxidant activity of Mangosteen (Garcinia mangostana L.) fruit rind extract in oral solution dosage form. In International Symposium on Medicinal Plants \& Traditional Medicine, Tawangmangu, 2014 June 4-6, Central Java Indonesia, 2014.

Supiyanti W, Wulansari ED, Kusmita L. Test of antioxidant activity and determination of total anthocyanin content in rind of mangosteen (Garcinia mangostana L). Majalah Obat Tradisional, 2010; 15:64-70.

Surveswaran S, Cai YZ, Corke H, Sun M. Systematic evaluation of natural phenolic antioxidants from 133 Indian medicinal plants. Food Chem, 2007; 102:938-53.

Suttirak W, Manurakchinakorn S. In vitro antioxidant properties of mangosteen peel extract. J Food Sci Technol, 2012; 51(12):3546-58.

Tachakittirungrod S, Okonogi S, Chowwanapoonpohn S 
Study on antioxidant activity of certain plants in Thailand: mechanism of antioxidant action of guava leaf extract. Food Chem, 2007; 103:381-8.

Tjahjani S, Widowati W, Khiong K, Suhendra A, Tjokropranoto

R. Antioxidant properties of Garcinia mangostana L (Mangosteen) rind. Procedia Chem, 2014; 13:198-203.

Wang M-H, Zhang K-J, Gu Q-L, Bi X-L, Wang J-X. Pharmacology of mangostins and their derivatives: a comprehensive review. Chin J Nat Med, 2017; 15:81-93.

Weecharangsan W, Opanasopit P, Sukma M, Ngawhirunpat T, Sotanaphun U and Siripong P. Antioxidative and neuroprotective activities of extracts from the fruit hull of mangosteen (Garcinia mangostana L.). Med Princ Pract, 2006; 15:281-7.

Wittenauer J, Falk S, Schweiggert-Weisz U, Carle R. Characterisation and quantification of xanthones from the aril and pericarp of mangosteens (Garcinia mangostana L.) and a mangosteen containing functional beverage by HPLC-DAD-MS ${ }^{n}$. Food Chem, 2012; 134:445-52.

Yang Z, Zhai W. Identification and antioxidant activity of anthocyanins extracted from the seed and cob of purple corn (Zea mays L.). Inn Food Sci Emerging Technol, 2010; 11:169-76.

Yu L, Zhao M, Yang B, Zhao Q, Jiang Y. Phenolics from hull of Garcinia mangostana fruit and their antioxidant activities. Food Chem, 2007; 104:176-81.
Zarena AS, Sankar UK. A study of antioxidant properties from Garcinia mangostana L. peel extract. Acta Sci Pol, 2009; 8:23-34.

Zarena AS, Sankar KU. Xanthones enriched extracts from mangosteen pericarp obtained by supercritical carbon dioxide process. SepPurif Technol, 2011; 80:172-8.

Zhong Y, Shahidi F. Methods for the assessment of antioxidant activity in foods. In: Shahidi $\mathrm{F}$ (ed.). Handbook of antioxidants for food preservation 2015, Woodhead Publishing, New York, NY, pp 287-333, 2015.

Zou Y, Kim AR, Kim JE, Choi JS, Chung HY. Peroxynitrite scavenging activity of sinapic acid (3,5-Dimethoxy-4-hydroxycinnamic Acid) isolated from Brassica juncea. J Agric Food Chem, 2005; 50: 5884-90.

\section{How to cite this article:}

Rohman A, Rafi M, Alam G, Muchtaridi M, Windarsih A. Chemical composition and antioxidant studies of underutilized part of mangosteen (Garcinia mangostana L.) fruit. J Appl Pharm Sci, 2019; 9(08):047-052. 